\title{
The Motivation of Learners of English as a Foreign Language Revisited
}

\author{
Hsuan-Yau Tony Lai ${ }^{1}$ \\ ${ }^{1}$ Department of Applied Foreign Languages, National Taipei College of Business, Taipei City, Taiwan \\ Correspondence: Hsuan-Yau Tony Lai, Department of Applied Foreign Languages, National Taipei College of \\ Business, Taipei City, 100, Taiwan. Tel: 886-2-2322-6607. E-mail: tony823@ms17.hinet.net
}

Received: August 26, 2013 Accepted: September 26, 2013 Online Published: September 28, 2013

doi:10.5539/ies.v6n10p90 URL: http://dx.doi.org/10.5539/ies.v6n10p90

\begin{abstract}
This study investigates Taiwanese university students' English learning orientation from the perspective of various important L2 motivation concepts (from Gardner's integrativeness/instrumentality to Dörnyei's L2 motivational self system) and the notion of English as an international language. The uniqueness also lies in its comparison and contrast of both day and night school students' motivation for studying English. A total of 267 undergraduate students from a science and technology university in New Taipei City, Taiwan, participated in this survey study. The results show that the majority of the participants studied English for travel, instrumental and integrative orientations, as well as intrinsic motivation and the ideal L2 self, but not for external pressure and the ought-to L2 self. No significant difference was found between day and night school students' motivation for studying English. The term "integrativeness/integrative orientation", which has been rooted in L2 motivation research for decades, is re-examined in this study, especially with the current important status of the English language in the world. This paper will consider possible implications for English language professionals to reconceptualise and re-approach EFL learners' motivation to study English.
\end{abstract}

Keywords: motivation, English as an international language, ideal self, ought-to self

\section{Introduction}

Motivation is perhaps one of the most important elements in the process of second/foreign language learning. It has a huge impact on an L2 learner's learning outcome. L2 motivation research has gone through different stages and researchers have conceptualised various L2 motivation models in the field, from Gardner's socio-educational model $(1985,2001,2005)$ to Dörnyei's L2 Motivational Self System (2005, 2009, see also Dörnyei \& Ushioda, 2011). Many researchers have contributed to L2 motivation research in various contexts, such as English as a Second Language (ESL) and English as a Foreign Language (EFL). One of the founders of L2 motivation research is perhaps Gardner and his associates in Canada, with their proposed socio-educational model featuring integrativeness/integrative motivation and instrumentality. However, in recent years, Gardner's (1985, 2001, 2005) concept of learning a second language in order to get closer to another language community has been questioned. With the increasing importance of English and its current status as the most important international language in today's world, do English learners study English in order to get closer to particular communities (in the case of the English language, English-speaking countries/communities)? In Taiwan, English is taught and learnt as a foreign language (an EFL context). Most students in Taiwan have little or no contact with the native speakers of English; however, studying English seems to have become a national activity among school pupils, company employees and others in Taiwan due to its important global status.

The paper aims to explore Taiwanese students' motivation for studying English from the perspectives of English as an international language and the latest L2 motivation theory (the L2 Motivational Self System). As well as this major aim, in this study, a comparison and contrast between day and night school students' English learning motivation will also be discussed. In Taiwan, many universities have both day and night programmes within the same academic department (e.g. the English department). Normally, night school students come to campus to attend classes in the evening. After they meet the requirements for graduation, they will be awarded a bachelor's or a master's degree as day school students are. From my personal teaching observation as a university English teacher of both English-major and non-English-major students, I have found from time to time that most night school students tend to have strong motivation and show enthusiasm for learning English, even after they have a 
hard day at work. Some of them want to improve their English knowledge because they need it for work, for travel or purely and simply because they want to study English for pleasure and enjoyment, which inspires them to enrol on the night programme. On the other hand, some day school students seem to lack motivation in the English classroom. As Chern (2002, p. 97) argues, in Taiwan, "students' motivation for learning English has remained at the level sufficient either to fulfil the course requirements or to pass the entrance examinations to the next level of schooling." These observations have triggered the present study, which aims to explore Taiwanese English learners' motivation for studying English with an emphasis on a comparison and contrast of both day and night school students.

\section{Literature Review}

In this literature review, relevant theories and concepts about L2 motivation will be discussed.

\subsection{Gardner's Motivation Theory}

Gardner's motivation theory has been profoundly influential in the L2 motivation field for decades. According to Gardner (2001), motivation includes three elements - effort (the effort to learn the language), desire (wanting to achieve a goal) and positive affect (enjoy the task of learning the language). The role of orientations, which Gardner refers to as a "goal" aims to arouse motivation and direct it to reach the goals (Gardner, 1985). Two orientations in particular - integrative orientation and instrumental orientation - were introduced by Gardner and his associates and have been discussed and explored in L2 motivation research extensively. According to Gardner (1985), integrative orientation refers to a positive attitude towards the L2 community and the desire to get close to the community and even become a member of that community. As a counterpart to integrative orientation, instrumental orientation is defined as learning an L2 for pragmatic reasons, such as getting a better job or a higher salary.

The most influential and well-known embodiment of Gardner's motivation theory is perhaps the socio-educational model. The model was first proposed by Gardner and Smythe (1975) and has undergone a number of changes since then (see, for example, Gardner, 1985; Gardner \& MacIntyre, 1993; Gardner, 2000; Gardner, 2005). The integrative dimension (integrativeness, integrative motivation, integrative motive and integrative orientation) in this model has given many scholars confusion in the past decades. As Dörnyei (1994) argues, the terms integrative motive/motivation, integrativeness and integrative orientation are confusing and seem to be interchangeable. As well as this, the definition of integrativeness seems to vary slightly from time to time. For instance, it refers to an individual's willingness and interest in social interaction with members of other groups (Gardner \& MacIntyre, 1993, p. 159). In another Gardner article, the definition reflects "a genuine interest in learning the second language in order to come closer to the other language community" (Gardner, 2001, p.5). Furthermore, Gardner (ibid.) explains that integrativeness involves two levels. At one level, it refers to openness towards other cultural groups. At the other extreme level, it involves "complete identification with the community (and possibly even withdrawal from one's original group)." Gardner (2001, p.1) himself also points out that the term has "slightly different meanings to many different individuals."

In order to avoid any ambiguity and confusion, Gardner (2005) has tried to clarify some of the confusion and proposed an amended version of the socio-educational model (see Figure 1). In this model, he claims that two major variables (Motivation and Ability, which includes intelligence and language aptitude) are strongly linked to an individual's achievement in the language learning context and that an individual's motivation to learn an L2 is related to two variables - Integrativeness and Attitudes to Learning Situation. Attitudes to learning situation include elements, such as teachers, instructions, curriculum, lesson plans, and evaluation processes. The variable integrativeness, which he refers to as an important element in influencing motivation, is defined and clarified by him. As he argues:

We never meant integrativeness (or integrative orientation, or integrative motive) to mean one wanted to become a member of the other cultural community, but rather an individual's openness to taking on characteristics of another cultural/linguistic group (Gardner, 2005, p. 7). 


\section{The Socio-educational Model}

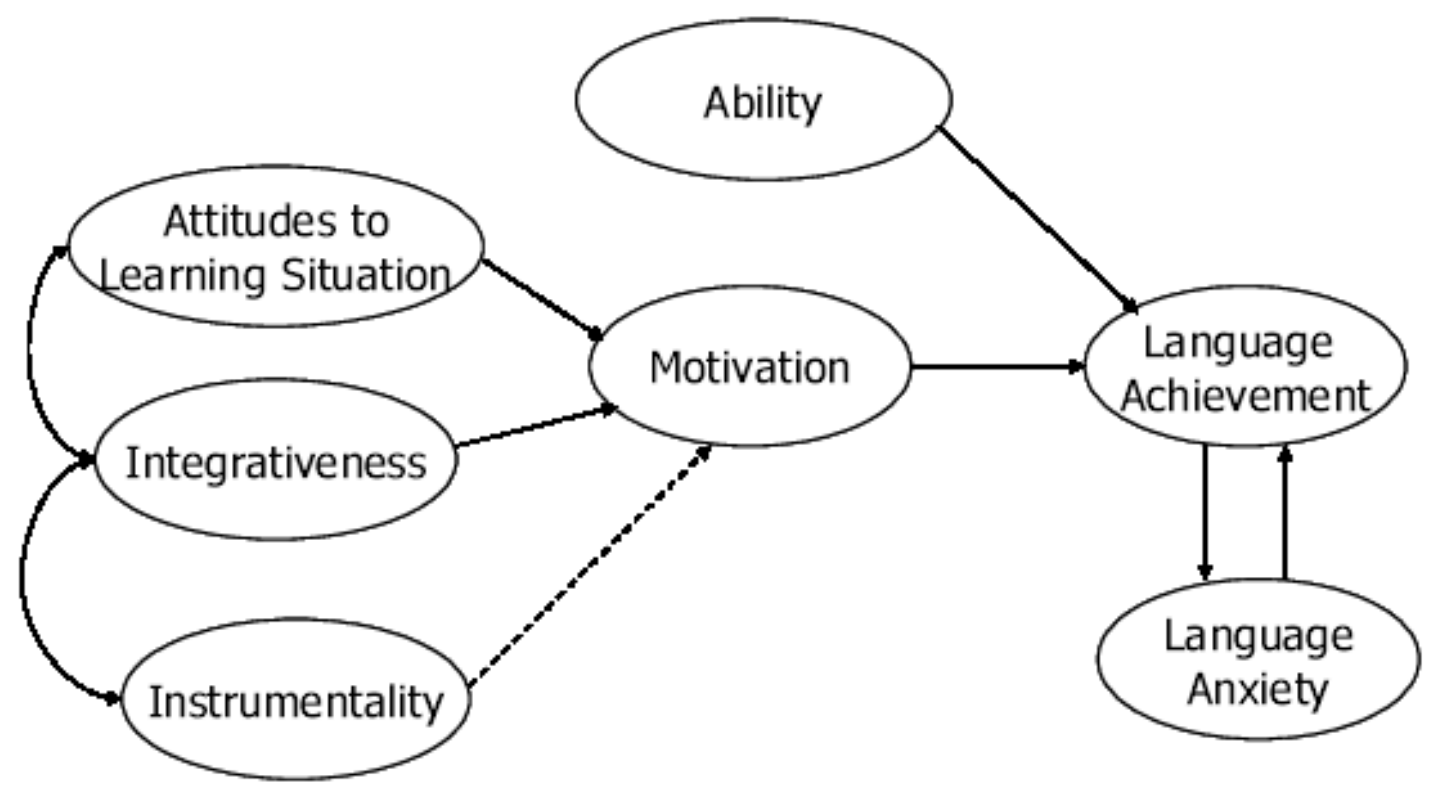

Figure 1. Gardner's socio-educational model

Another variable that influences language achievement is Instrumentality, which refers to learning a language for practical reasons. According to Gardner (2005), instrumentality and integrativeness are mediated by motivation. Furthermore, he asserts that these three constructs (Attitudes to Learning Situation, Integrativeness and Instrumentality) are positively correlated with one another. In other words, learners with high integrativeness view the language learning situation positively and have high levels of instrumentality.

Gardner's socio-educational model has been a pioneering and influential L2 motivation model and has been used to test many hypotheses in the field for more than two decades. However, the core notion of the model - integrativeness - has been critiqued by some scholars (see, for example, Coetzee-Van Rooy, 2006; Dörnyei, 2005, 2009; Dörnyei \& Ushioda, 2011; Dörnyei, Csizér, \& Németh, 2006; Kachru \& Nelson, 2006; Lamb, 2004; McClelland, 2000; Norton, 2000; Yashima, 2000, 2009). Since English is in a unique position as an international language today, whether the notion of integrativeness is applicable to every English language learner in different educational settings (e.g. EFL) needs to be re-examined. Here, I will briefly discuss this issue from the perspective of English as an international language.

\subsection{English as an International Language}

The concept of English as an international language has been discussed extensively in the fields of Second Language Acquisition (SLA) and Applied Linguistics. It mainly centres on three notions: the ownership of English, varieties of English and native norms of English. According to Harmer (2007), the English language has reached its significant status today because of the colonial history of the British Empire, economic factors, information exchange, travel, and popular culture. Graddol (2006) even predicts that there will be about three billion English speakers by the year 2040. Since much communication in English today involves non-native English speakers only, scholars are questioning the ownership of English (see, for example, Jenkins, 2003, 2011; McKay, 2002, 2003). They argue that English is no longer exclusive to any English-speaking countries or communities, but is, in fact, shared by people who speak it in order to communicate across different linguistic and cultural boundaries. In terms of varieties of English, the suggestion is that, apart from countries where English is used as a mother tongue (e.g. the UK, the US, Canada, Australia, etc.), there are countries where local people have developed indigenised (or localised) varieties of English today (e.g. India, Singapore, Malaysia, etc...). Many of these countries were the past colonies of the British Empire. As well as these two groups, other countries are commonly categorised as an EFL context where English is used as a foreign language and for international communication (e.g. Taiwan, China, Japan, Korea, etc.) (for discussion, see, Kachru, 1985; Kachru 
\& Nelson, 2006). The debate on the ownership of English and the reality of the varieties of English in the world have prompted scholars to question the appropriateness of following the English as a Native Language (ENL) model (i.e. the aspiration to possess native English speakers' communicative competence) in the English classroom (see, Jenkins, 2003, 2011; McKay, 2002, 2003; Nelson, 1995; Kachru \& Nelson, 2006). Alptekin (2002, p.57) even criticises the native pedagogic model based on the notion of communicative competence as being utopian, unrealistic, and constraining.

\subsection{The L2 Motivational Self System}

As discussed in Section 2.1, Gardner's notion of integrativeness has caused confusion and debate in the L2 motivation field. For example, if integrativeness refers to "an individual's openness to taking on characteristics of another cultural/linguistic group"(Gardner, 2005, p.7), then whose characteristics should English language learners take on, if English is an international language shared by everyone who speaks it for communication in today's world? This is discussed in Section 2.2. Nevertheless, due to the dissatisfaction with Gardner's notion of integrativeness (see, for example, Coetzee-Van Rooy, 2006; Dörnyei, 2005, 2009; Dörnyei \& Ushioda, 2011; Dörnyei et al., 2006; Kachru \& Nelson, 2006; Lamb, 2004; McClelland, 2000; Norton, 2000; Yashima, 2000, 2009), Dörnyei $(2005,2009)$ has developed the L2 Motivation Self System while retaining some of the framework of L2 motivation. According to Dörnyei and Ushioda (2011, p. 86), the L2 Motivational Self System consists of three components, which are:

1. Ideal L2 Self, which is the L2-specific facet of one's 'ideal self'. If the person we would like to become speaks an L2, the 'ideal L2 self' is a powerful motivator to learn the L2 because of the desire to reduce the discrepancy between our actual and ideal selves.

2. Ought-to L2 Self, which concerns the attributes that one believes one ought to possess to meet expectations and to avoid possible negative outcomes.

3. L2 Learning Experience, which concerns situated, 'executive' motives related to the immediate learning environment and experience (e.g. the impact of the teacher, the curriculum, the peer group or the experience of success).

As we can see from these three components, Dörnyei's L2 Self System is mainly based on an individual's own vision of speaking an L2. Instead of putting an emphasis on integration into any particular language or cultural group, he believes that an L2 learner has a powerful imagined self. During the process of studying the L2, this very L2 learner comes closer to his/her ideal L2 self and/or ought-to L2 self. Furthermore, he claims that it is likely that there is a link between integrative and internalised instrumental orientations (e.g. approaching a personal goal) and the ideal L2 self; external types of instrumental motives (e.g. avoiding punishments) and the ought-to L2 self; the immediate learning environment and experience and L2 learning experience. Dörnyei's L2 Self System has provided L2 motivation researchers with a different and broad perspective to approach or reconceptualise L2 motivation. Since Gardner put forward his first socio-educational model back in the 1970s (Gardner \& Smythe, 1975), L2 motivation research has been profoundly influenced by the notion of integrativeness and instrumentality. Nevertheless, with the importance of English and its current global status, studying English in order to become a member of (or come closer to) the target language community seems questionable.

\subsection{Self-Determination Theory}

Before moving to the methodology of this study, I would like to briefly discuss another important theorySelf-Determination Theory (i.e. intrinsic and extrinsic motivation) - in motivation research. Although these two orientations - intrinsic and extrinsic motivation - are generally used to describe human motivation rather than L2 motivation, they are still strongly associated with L2 motivation in various ways. As Ryan and Deci (2000) claim, both intrinsic and extrinsic motivation are important to educators. Figure 2 shows the schema of the theory. 
Behaviour
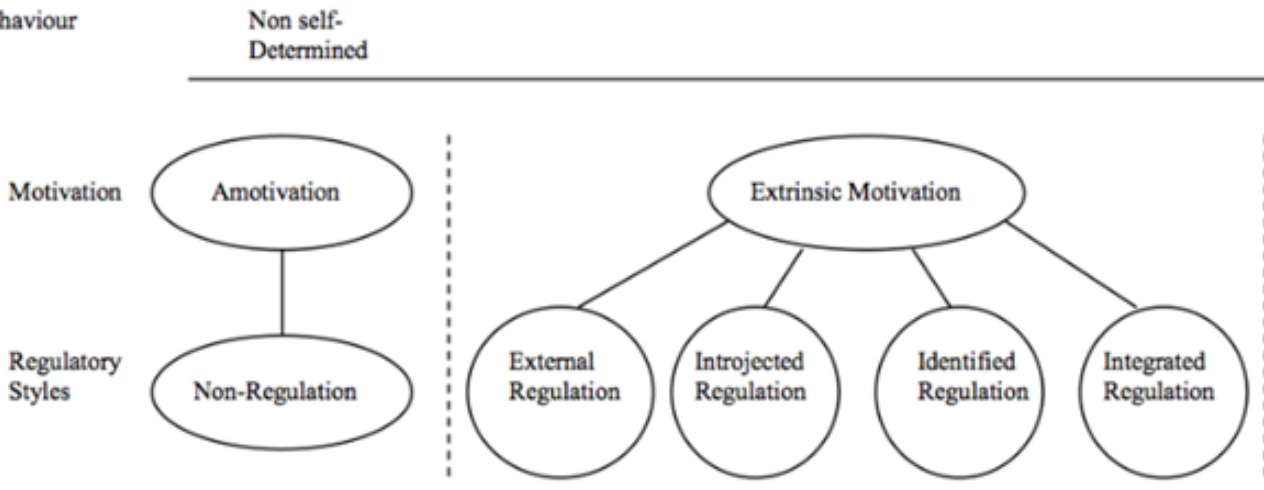

Self-Determined

Perceived Locus of Causality

Relevant Regulatory Processes
Impersonal

Non-intentional, Non-valuing, Incompetence, Lack of Control

\begin{abstract}
External
Compliance,

External

Rewards and

Punishments
\end{abstract}

Somewhat External
Somewhat

Internal
Internal

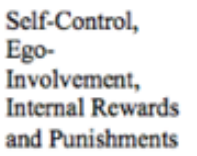

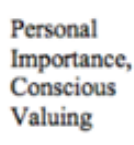

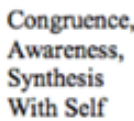

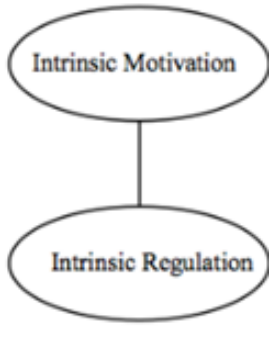

Internal

Figure 2. A taxonomy of human motivation

According to Deci and Ryan (1985; see also Ryan \& Deci, 2000), there are several types of human motivation. On the far left is Amotivation, which refers to a lack of any intention to act. Amotivation is not caused by internal or external factors but rather shows an individual's lack of competence when doing an activity. In the middle of the continuum is Extrinsic Motivation, which refers to doing an activity for its instrumental value rather than for pleasure or enjoyment. Extrinsic motivation is categorised into four different subtypes-External Regulation, Introjection (or Introjected Regulation), Identification (or Identified Regulation) and Integration (or Integrated Regulation) - which reflect different degrees of autonomy and self-determination through the processes of internalisation (to take in a value or regulation) and integration (to transform the value or regulation to the individual's own). Dörnyei (2009) believes that the ideal L2 self to some extent is in association with more internalised instrumental motivation and that the ought-to L2 self leans towards the external end of extrinsic motivation. In contrast to extrinsic motivation, Intrinsic Motivation refers to doing an activity for its inherent pleasure and enjoyment rather than external consequences.

According to Ryan and Deci (2000), the intrinsic/extrinsic motivation continuum illustrates a process of motivational change. However, they believe that human motivation is not necessarily developed through each stage as a sequence and might "move back and forth" between orientations. For example, a person may start to do an activity because of a reward (external regulation); however, during the process, the person may find $\mathrm{him} /$ her doing well in the activity and this gradually arouses his/her intrinsic motivation. In this case, the individual may skip the other orientations within the extrinsic motivation domain. Furthermore, Noels (2001) argues that a person may have more than one orientation (goal) for learning a second/foreign language simultaneously, although some are more important than others.

In this literature review, I discussed L2 motivation from various perspectives, such as Gardner's socio-educational model, English as an international language, Dörnyei's L2 Motivational Self System and Self-Determination Theory. In the next section, I will outline the methodology of this study.

\section{Methodology}

The section will introduce the research design of the study, including the participants, method, data collection, analysis and limitations.

\subsection{Participants}

The study involves English major students, including both day and night school students from an applied English department of a science and technology university in New Taipei City (suburban Taipei City). The department places its focus on training their students to become fluent in English (the four skills of English-reading, writing, listening and speaking) with other professional skills, such as teaching English to speakers of other 
languages (TESOL), translation (or interpretation) and business English.

\subsection{Method}

In order to generate a large amount of data in a short period of time, a survey was conducted. A standardised questionnaire in both English and Chinese was used. Chen (2010) had developed this questionnaire during the course of her doctoral research, which explored senior high school students' English learning motivation in Taiwan. Although her participants were high school students, she used the questionnaire to explore a similar topic (Taiwanese English learners' motivation), and I believe that the questionnaire has good reliability and validity. There were three sections in the questionnaire: 1. Student Profile; 2. Motivation Orientations (44 Likert-scale items); 3. Other Comments (See Appendix). The second section (motivation orientations) is made up of seven different motivation orientations, which were 1. integrative orientation (Item 1, 3, 5, 6, 8, 10, 11, 13), 2. instrumental orientation (Item 2, 4, 7, 9, 12, 14), 3. intrinsic motivation (Item 15, 17, 19, 21, 23, 24, 26, 28, 30), 4. external pressure $(16,18,20,22,25,27)$, 5. ideal L2 self (Item 29, 31, 33, 35, 37, 39, 41, 43), 6. ought-to L2 self (Item 32, 34, 36, 38), and 7. travel orientation (Item 40, 42, 44). Each respondent had to rate the items on a scale from 1 to 4 (1=strongly disagree; $2=$ disagree; $3=$ agree; $4=$ strongly agree). In the literature review (Section 2), I discussed the controversy of integrativeness (or integrative orientation). Although the notion is a debatable issue, we may assume that some English learners might want to study English because they are interested in the target language countries/communities and is one of their motives. Therefore, integrative orientation was still included in the questionnaire for the study. However, in order to broaden the scope of integrative orientation, instead of putting a focus on "English-speaking countries" only, Chen (2010) also put "foreign countries" in her questionnaire. For example, Item 3-I like the people who live in English-speaking (or foreign) countries - was used to investigate respondents' opinions of integrative orientation (for other items, see Appendix). The third section (Other Comments) of the questionnaire was an open-ended question: Is there any comment regarding your attitude to learning English and/or to the above issue (Motivational Orientations)? Respondents were welcome to express any of their thoughts or suggestions in this section.

\subsection{Data Collection}

The questionnaire was administered over a one month period. I went to most classes (both day and night classes) in the English department and explained the purpose of my study to the students, and I asked for their verbal consent prior to administering the questionnaire. The students' participation was voluntary and their identity is remained anonymous. The participants were given as much time as they needed when filling out the questionnaire. A total of 267 questionnaires were collected. The distribution of the respondents is as follows:

Table 1. Distribution of the respondents (School Year)

\begin{tabular}{cccc}
\hline Year 1 & Year 2 & Year 3 & Year 4 \\
\hline $\mathrm{N}=93(34.83 \%)$ & $\mathrm{N}=74(27.72 \%)$ & $\mathrm{N}=37(13.86 \%)$ & $\mathrm{N}=63(23.60 \%)$ \\
\hline
\end{tabular}

Table 2. Distribution of the respondents (Day and Night Schools)

\begin{tabular}{cc}
\hline Day school & Night school \\
\hline $\mathrm{N}=192(72.18 \%)$ & $\mathrm{N}=74(27.82 \%)$ \\
\hline
\end{tabular}

Table 3. Distribution of the respondents (Gender)

\begin{tabular}{cc}
\hline Male & Female \\
\hline $\mathrm{N}=63(23.60 \%)$ & $\mathrm{N}=204(76.40 \%)$ \\
\hline
\end{tabular}

\subsection{Data Analysis and Limitations}

After the data were collected, they were analysed using an internal consistency (Cronbach's Alpha) test, descriptive statistics, and a t-test, with the help of SPSS 15 for Windows (Statistical Package for the Social Sciences). An internal consistency test was run to check the homogeneity of the multi-item orientations. The results show that the internal consistency reliability (Cronbach's Alpha) for each orientation was more than 0.70 , which indicates that each orientation reached its homogeneity (see Table 4). 
Table 4. Internal consistency reliability for seven orientations

\begin{tabular}{ccccccc}
\hline $\begin{array}{c}\text { Integrative } \\
\text { orientation } \\
(8 \text { items })\end{array}$ & $\begin{array}{c}\text { Instrumental } \\
\text { orientation } \\
(6 \text { items })\end{array}$ & $\begin{array}{c}\text { Intrinsic } \\
\text { motivation } \\
(9 \text { items })\end{array}$ & $\begin{array}{c}\text { External } \\
\text { Pressure } \\
(6 \text { items })\end{array}$ & $\begin{array}{c}\text { Ideal L2 } \\
\text { self } \\
(8 \text { items })\end{array}$ & $\begin{array}{c}\text { Ought-to } \\
\text { L2 self } \\
(4 \text { items })\end{array}$ & $\begin{array}{c}\text { Travel } \\
\text { Orientation } \\
(3 \text { items })\end{array}$ \\
\hline 0.86 & 0.80 & 0.87 & 0.75 & 0.90 & 0.75 & 0.82 \\
\hline
\end{tabular}

None of the participants ( $\mathrm{N}=267)$ answered the open-ended question at the end of the questionnaire. Therefore, no qualitative data were analysed for the study.

There are some limitations to the study. First, the data were collected in one university in suburban Taipei City, which might not be representative of the majority of the university students in Taiwan. However, since most of the students (about three-quarters) in the English department of this particular university participated in the survey, I believe the results still shed some light on how we see and think about EFL learners' motivation for studying English. Second, English learners' motivation may vary in different way and perhaps many of them have more than one motive to study English, as discussed in the literature review. Although I believe that the seven orientations in the questionnaire covered various aspects of English learning motivation, some participants might still find that their motives for learning English were not mentioned in the questionnaire. It is a pity that no respondent answered the open-ended question, so it is not clear whether they had some other suggestions or motives for studying English or not.

\section{Findings and Discussion}

This study aims to explore Taiwanese English learners' motivation for studying English, with an emphasis on a comparison and contrast of day and night school students' motivation. The results (t-test result) show that there is no significant difference between day and night school students' motivation to study English (see Figure 3). In other words, day and night school participants in the study shared similar orientations when studying English.

Group Statistics

\begin{tabular}{|ll|r|r|r|r|}
\hline & school & \multicolumn{1}{|c|}{$\mathrm{N}$} & \multicolumn{1}{c|}{ Mean } & Std. Deviation & Std. Error Mean \\
\hline Integrative & Daytime & 192 & 3.1743 & .47609 & .03436 \\
& Nighttime & 74 & 3.0922 & .57480 & .06682 \\
\hline \multirow{2}{*}{ Instrumental } & Daytime & 192 & 3.1967 & .48400 & .03493 \\
& Nighttime & 74 & 3.1216 & .58410 & .06790 \\
\hline Intrinsic & Daytime & 192 & 3.0329 & .50909 & .03674 \\
& Nighttime & 74 & 3.0253 & .61403 & .07138 \\
\hline External & Daytime & 192 & 2.2498 & .52437 & .03784 \\
& Nighttime & 74 & 2.0968 & .65341 & .07596 \\
\hline \multirow{2}{*}{ Ideal } & Daytime & 192 & 3.0483 & .55355 & .03995 \\
& Nighttime & 74 & 2.9884 & .66269 & .07704 \\
\hline \multirow{2}{*}{ Ought } & Daytime & 192 & 2.5221 & .64672 & .04667 \\
& Nighttime & 74 & 2.4426 & .80935 & .09408 \\
\hline \multirow{2}{*}{ Travel } & Daytime & 192 & 3.2326 & .64199 & .04633 \\
& Nighttime & 74 & 3.1351 & .80697 & .09381 \\
\hline
\end{tabular}

Figure 3. T-test Results for day and night school participants

Under this circumstance, what is the learning motivation of these participants? In descending order, Figure 4 shows that the participants studied English for travel orientation (Mean=3.20), instrumental orientation (Mean=3.17), integrative orientation (Mean=3.14), the ideal L2 self (Mean=3.0315) and intrinsic motivation (Mean=3.0307). In contrast, they did not study English for external pressure (Mean=2.21) or the ought-to L2 self (Mean=2.50). Since all of the participants were English majors, we may assume that they chose English to be 
their major because they felt like studying it and/or needed it in their future studies and career. Therefore, the mean scores for external pressure and the ought-to L2 self were lower than the other orientations.

\section{Descriptive Statistics}

\begin{tabular}{|l|r|r|r|r|c|}
\hline & \multicolumn{1}{|c|}{$\mathrm{N}$} & \multicolumn{1}{c|}{ Minimum } & Maximum & \multicolumn{1}{c|}{ Mean } & Std. Deviation \\
\hline Integrative & 267 & 1.00 & 4.00 & 3.1495 & .50578 \\
Instrumental & 267 & 1.00 & 4.00 & 3.1745 & .51323 \\
Instrinsic & 267 & 1.00 & 4.00 & 3.0307 & .53813 \\
External & 267 & 1.00 & 4.00 & 2.2102 & .56715 \\
Ideal & 267 & 1.00 & 4.00 & 3.0315 & .58418 \\
Ought & 267 & 1.00 & 4.00 & 2.5019 & .69448 \\
Travel & 267 & 1.00 & 4.00 & 3.2047 & .69045 \\
Valid N (listwise) & 267 & & & & \\
\hline
\end{tabular}

Figure 4. Participants' motivation for studying English

In order to give more detailed analysis and discussion, Spearman's rho $p$ correlation test was run to see the correlations among the seven orientations. Table 5 shows that the ideal L2 self has a correlation with intrinsic motivation (in bold), travel orientation (in bold), integrative orientation (in bold) and instrumental orientation (in bold). The ought-to L2 self is in association with external pressure (in bold). These findings echo Dörnyei's $(2005,2009)$ claim that integrative orientation and more internalised instrumental motives are closer to the notion of the ideal L2 self, and that the ought-to L2 self is in relation to more external types of instrumental motivation.

Table 5. Correlations (Spearman's rho)

\begin{tabular}{|c|c|c|c|c|c|c|c|}
\hline & Integrative & Instrumental & Intrinsic & External & Ideal & Ought-to & Travel \\
\hline Integrative & 1.000 & $.634 * *$ & $.699 * *$ & -.120 & $.618^{* *}$ & $.163 * *$ & $.703 * *$ \\
\hline Instrumental & $.634 * *$ & 1.000 & $.595 * *$ & $.136^{*}$ & $.569 * *$ & $.335^{* *}$ & $.590 * *$ \\
\hline Intrinsic & $.699 * *$ & $.595^{* *}$ & 1.000 & $-.187 * *$ & $.739 * *$ & .114 & $.615^{* *}$ \\
\hline External & -.120 & $.136^{*}$ & $-.187 * *$ & 1.000 & -.089 & $.581 * *$ & .003 \\
\hline Ideal & $.618 * *$ & $.569 * *$ & $.739 * *$ & -.089 & 1.000 & $.243 * *$ & $.635 * *$ \\
\hline Ought-to & $.163 * *$ & $.335 * *$ & .114 & $.581 * *$ & $.243 * *$ & 1.000 & $.215^{* *}$ \\
\hline Travel & $.703 * *$ & $.590 * *$ & $.615 * *$ & .003 & $.635 * *$ & $.215^{* *}$ & 1.000 \\
\hline
\end{tabular}

The majority of the participants in the study learnt English for travel, instrumental, integrative reasons and intrinsic motivation and these motives have a strong correlation with the ideal L2 self. To a large extent, I believe these EFL learners have the view that if they speak English fluently, they will be able to travel around the world, explore various countries and cultures, and be successful in their future studies and career. Moreover, they have this ideal L2 self "intrinsically" since the ideal L2 self has a strong link with intrinsic motivation (see Table 5). Here, I would like to draw on two notions to discuss these findings. I believe that Taiwanese EFL learners may have developed the idea of bicultural identity described in Arnett (2002). Arnett (ibid.) claims that since globalisation has become the most important trend in the world, an individual is under pressure to develop two identities. One is his/her local identity and the other is a global identity which connects him/her to the international community. Furthermore, Yashima (2000, 2002, 2009, see also Yashima, Zenuk-Nishide, \& Shimizu, 2004) proposes a similar notion - international posture - based on her research into Japanese EFL learners' motivation for studying English. She argues that many EFL learners might be inclined to interact with native English speakers, but they may have no intention to identify with the native speakers of English. Instead, 
she believes that many EFL learners have this "international posture" which refers to "a tendency to see oneself as connected to the international community, have concerns for international affairs and possess a readiness to interact with people other than Japanese" (in her case) (Yashima, 2009, p. 146). She further explores this notion by including three subcomponents: 1 . Intergroup approach tendency, 2. Interest in international vocation and activities, and 3. Interest in foreign affairs (Yashima, 2002, 2009, see also Yashima et al., 2004). Since English is perhaps the most important international language in today's world, learning English seems to have become a national activity in Taiwan, from school students to enterprise employees and civil servants. However, I believe that the idea of learning English in order to identify or come closer to native English speakers is dimming in Taiwan. Being able to communicate (or interact) with various people in different settings successfully in English is more meaningful than identifying with any particular community/group of people. The only community for EFL learners to integrate to is the "international" community.

\section{Conclusion}

This study investigated EFL learners' orientations for studying English by combining the notion of English as an international language and the latest motivation theory (the L2 Motivational Self System), with an emphasis on a comparison and contrast of day and night school students. The findings show that there is no significant difference between day and night school students' English learning motivation and that the majority of the participants studied English for travel, instrumental, integrative orientations, intrinsic motivation and the ideal L2 self, not because of external pressure and the ought-to L2 self. The findings also show that the ideal L2 self has a strong correlation with intrinsic motivation, and travel, integrative and instrumental orientations. Since English is one of the most important international languages nowadays, we might need to re-conceptualise the notion of integrative orientation when discussing an English learner's intention to study the language. For EFL learners who have little or no contact with native English speakers, an imagined L2 self is perhaps a powerful light to guide them to become successful English users through the learning process and to step into this global village. At the end of this paper, I would like to provide some suggestions for English language teaching (ELT) professionals by drawing on Dörnyei's (2009) idea of utilising the ideal L2 self to motivate EFL learners. If we (English teachers and ELT professionals) can help English learners to create (through awareness raising and guided selection from the various hopes and dreams), strengthen and sustain a vision, and to develop an action plan to operationalise their vision, these English learners will eventually overcome the difficulties in learning English and become autonomous learners.

\section{References}

Alptekin, C. (2002). Towards intercultural communicative competence in ELT. ELT Journal, 56(1), 57-64. http://dx.doi.org/10.1093/elt/56.1.57

Arnett, J. J. (2002). The psychology of globalization. American Psychologist, 57, 774-783. http://dx.doi.org/10.1037/0003-066X.57.10.774

Chen, S. A. (2010). Using Mixed Methods to Explore L2 Motivation: A Study of Senior High School English Learners in Taiwan. (Unpublished doctoral dissertation). Warwick University, Coventry, UK.

Chern, C. 1. (2002). English Language Teaching in Taiwan Today. Asia-Pacific Journal of Education, 22(2), 97-105. http://dx.doi.org/10.1080/0218879020220209

Coetzee-Van Rooy, S. (2006). Integrativeness: Untenable for world Englishes learners. World Englishes, 25, 3/4, 437-450. http://dx.doi.org/10.1111/j.1467-971X.2006.00479.x

Deci, E. L., \& Ryan, R. M. (1985). Intrinsic motivation and self-determination in human behavior. New York: Plenum. http://dx.doi.org/10.1007/978-1-4899-2271-7

Dörnyei, Z. (1994). Understanding L2 Motivation: On with the Challenge!. Modern Language Journal, 78(iv), 515-523.

Dörnyei, Z. (2005). The Psychology of the Language Learner: Individual Differences in Second Language Acquisition. London: Lawrence Erlbaum Associates. http://dx.doi.org/10.1017/S0272263105370288

Dörnyei, Z. (2009). The L2 Motivational Self System. In Z. Dörnyei, \& E. Ushioda (Eds.), Motivation, Language Identity and the L2 Self (pp. 9-42). Bristol: Multilingual Matters.

Dörnyei, Z., \& Ushioda, E. (2011). Teaching and Researching Motivation (2nd ed.). Harlow: Pearson Education Limited.

Dörnyei, Z., Csizér, K., \& Németh, N. (2006). Motivation, Language Attitudes and Globalisation: A Hungarian Perspective. Clevedon: Multilingual Matters. 
Gardner, R. C. (1985). Social Psychology and Second Language Learning: The Role of Attitudes and Motivation. London: Edward Arnold.

Gardner, R. C. (2000). Correlation, causation, motivation and second language acquisition. Canadian Psychology, 41, 1-24. http://dx.doi.org/10.1037/h0086854

Gardner, R. C. (2001). Integrative motivation and second language acquisition. In Z. Dörnyei, \& R. Schmidt (Eds.), Motivation and Second Language Acquisition (pp. 1-19). Hawaii: University of Hawaii Press.

Gardner, R. C. (2005). Integrative motivation and second language acquisition. Joint plenary talk at Canadian Association of Applied Linguistics/Canadian Linguistics Association, May.

Gardner, R. C., \& MacIntyre, P. D. (1993). A student's contributions to second language learning. Part II: Affective variables. Language Teaching, 26, 1-11. http://dx.doi.org/10.1017/S0261444800000045

Gardner, R. C., \& Smythe, P. C. (1975). Motivation and second-language acquisition. The Canadian Modern Language Review, 31, 218-230.

Graddol, D. (2006). English Next. The British Council.

Harmer, J. (2007). The Practice of English Language Teaching. Harlow: Pearson Education Limited.

Jenkins, J. (2003). World Englishes: A resource book for students. London: Routledge.

Jenkins, J. (2011). Accommodating (to) ELF in the international university. Journal of Pragmatics, 43, 926-936. http://dx.doi.org/10.1016/j.pragma.2010.05.011

Kachru, B. B. (1985). Standards, codification and sociolinguistic realism: the English language in the outer circle. In R. Quirk, \& H. G. Widdowson (Eds.), English in the world: Teaching and learning the language and literatures (pp. 11-30). Cambridge: Cambridge University Press.

Kachru, Y., \& Nelson, C. L. (2006). World Englishes in Asian Contexts. Hong Kong: Hong Kong University Press.

Lamb, M. (2004). Integrative motivation in a globalizing world. System, 32, 3-19. http://dx.doi.org/10.1016/j.system.2003.04.002

McClelland, N. (2000). Goal orientations in Japanese college students learning EFL. In S. Cornwell, \& P. Robinson (Eds.), Individual differences in foreign language learning: Effects of aptitude, intelligence, and motivation (pp. 99-115). Tokyo: Japanese Association for Language Teaching.

McKay, S. L. (2002). Teaching English as an International Language: Rethinking Goals and Approaches. Oxford: Oxford University Press.

McKay, S. L. (2003). Toward an appropriate EIL pedagogy: Re-examining common ELT assumptions. International Journal of Applied Linguistics, 13(1), 1-22. http://dx.doi.org/10.1111/1473-4192.00035

Nelson, C. L. (1995). Intelligibility and world Englishes in the classroom. World Englishes, 14(2), 273-279. http://dx.doi.org/10.1111/j.1467-971X.1995.tb00356.x

Noels, K. A. (2001). New Orientations in Language Learning Motivation: Towards a Model of Intrinsic, Extrinsic, and Integrative Orientations and Motivation. In Z. Dörnyei, \& R. Schmidt (Eds.), Motivation and Second Language Acquisition (pp. 43-68). Hawaii: University of Hawaii Press.

Norton, B. P. (2000). Identity and Language Learning: Gender, Ethnicity and Educational Change. Singapore: Longman.

Ryan, R. M., \& Deci, E. L. (2000). Intrinsic and Extrinsic Motivations: Classic Definition and New Directions. Contemporary Educational Psychology, 25, 54-67. http://dx.doi.org/10.1006/ceps.1999.1020

Yashima, T. (2000). Orientations and motivations in foreign language learning: A study of Japanese college students. JACET Bulletin, 31, 121-133.

Yashima, T. (2002). Willingness to communicate in a second language: The Japanese EFL context. Modern Language Journal, 86, 54-66. http://dx.doi.org/10.1111/1540-4781.00136

Yashima, T. (2009). International Posture and the Ideal L2 Self in the Japanese EFL Context. In Z. Dörnyei, \& E. Ushioda (Eds.), Motivation, Language Identity and the L2 Self (pp. 144-163). Bristol: Multilingual Matters.

Yashima, T., Zenuk-Nishide, L., \& Shimizu, K. (2004). The influence of attitudes and affect on willingness to communicate and second language communication. Language Learning, 54, 119-152. http://dx.doi.org/10.1111/j.1467-9922.2004.00250.x 


\section{Appendix}

1. Student Profile (Please tick the appropriate space)

1. Gender: __ Male __ Female

2. Year of Study: $\_1 \_2 \_3 \_4$

3. School: __ day school __ night school

4. Major: ___ English majors ___ Non-majors

\section{Motivational Orientations}

Here are statements regarding your motivation for studying English. Please read the following statements carefully, and decide how strongly you agree or disagree with them by circling (o) around the appropriate number from 1 to 4 that you prefer. There is no right or wrong answer. $(1=$ Strongly Disagree; $2=$ Disagree; $3=$ Agree; 4= Strongly Agree)

\begin{tabular}{|c|c|}
\hline 1. I like English. & 1234 \\
\hline 2. I study English because it will be useful in getting a good job. & 1234 \\
\hline 3. I like the people who live in English-speaking (or foreign) countries. & 1234 \\
\hline 4. I study English because it will help me to obtain a higher paying job. & 1234 \\
\hline 5. I like meeting people from English-speaking (or foreign) countries. & 1234 \\
\hline $\begin{array}{l}\text { 6. I want to learn more about the culture and art of English-speaking (or } \\
\text { foreign) countries. }\end{array}$ & 1234 \\
\hline $\begin{array}{l}\text { 7. I study English because it is an international language which I can use } \\
\text { to converse with foreign people. }\end{array}$ & 1234 \\
\hline $\begin{array}{l}\text { 8. English will allow me to meet more foreign people coming from } \\
\text { English-speaking (or foreign) countries. }\end{array}$ & 1234 \\
\hline $\begin{array}{l}\text { 9. I study English because English proficiency is necessary for } \\
\text { communication with foreign customers for my job in the future. }\end{array}$ & 1234 \\
\hline $\begin{array}{l}\text { 10. English will enable me to better understand and appreciate the } \\
\text { English (or foreign) way of life. }\end{array}$ & 1234 \\
\hline $\begin{array}{l}\text { 11. I would like to know more about people from English-speaking (or } \\
\text { foreign) countries. }\end{array}$ & 1234 \\
\hline 12. I study English because I am planning to study abroad. & 1234 \\
\hline 13. I would like to live in English-speaking (or foreign) countries. & 1234 \\
\hline 14. I study English because I will need it someday to get a degree. & 1234 \\
\hline 15. I enjoy the process of learning English. & 1234 \\
\hline 16. I study English because English is an assigned subject. & 1234 \\
\hline 17. I enjoy the satisfaction when I find out new things in English. & 1234 \\
\hline 18. I study English because of exams. & 1234 \\
\hline 19. I enjoy the high feeling while I chat with foreigners in English. & 1234 \\
\hline 20. My parents push me to study English. & 1234 \\
\hline 21. I enjoy the high feeling while I speak English. & 1234 \\
\hline 22. I study English because my family puts a lot of pressure on me. & 1234 \\
\hline $\begin{array}{l}\text { 23. I study English for the confidence and the sense of achievement I } \\
\text { experience when succeeding in learning English. }\end{array}$ & 1234 \\
\hline 24. Studying English will enable me to broaden my view. & 1234 \\
\hline
\end{tabular}




\begin{tabular}{|c|c|}
\hline 25. I study English because of teacher's praise. & 1234 \\
\hline $\begin{array}{l}\text { 26. I study English for the pleasure I get from hearing English spoken } \\
\text { by native English speakers. }\end{array}$ & 1234 \\
\hline 27. I would feel ashamed if I got bad grades in English. & 1234 \\
\hline 28. I think English is an interesting subject. & 1234 \\
\hline 29. I can imagine myself as someone who is able to speak English. & 1234 \\
\hline 30. I can better understand what I'm interested in through using English. & 1234 \\
\hline $\begin{array}{l}\text { 31. I can imagine myself speaking English with international friends or } \\
\text { colleagues. }\end{array}$ & 1234 \\
\hline 32. I study English because close friends of mine think it is important. & 1234 \\
\hline 33. The things I want to do in the future require me to speak English. & 1234 \\
\hline $\begin{array}{l}\text { 34. Learning English is necessary because people surrounding me } \\
\text { expect me to do so. }\end{array}$ & 1234 \\
\hline $\begin{array}{l}\text { 35. I can imagine myself living abroad and using English effectively for } \\
\text { communicating with the locals. }\end{array}$ & 1234 \\
\hline $\begin{array}{l}\text { 36. I consider learning English important because the people I respect } \\
\text { think that I should do it. }\end{array}$ & 1234 \\
\hline 37. I can imagine myself reading English texts easily. & 1234 \\
\hline $\begin{array}{l}\text { 38. Studying English is important to me because I want to gain the } \\
\text { approval of my peers/teachers/family. }\end{array}$ & 1234 \\
\hline $\begin{array}{l}\text { 39. I can imagine myself being in a situation where I am speaking } \\
\text { English with foreigners. }\end{array}$ & 1234 \\
\hline $\begin{array}{l}\text { 40. I study English because I would like to visit English-speaking } \\
\text { countries. }\end{array}$ & 1234 \\
\hline $\begin{array}{l}\text { 41. I can imagine myself speaking English as if I were a native speaker } \\
\text { of English. }\end{array}$ & 1234 \\
\hline 42. I study English because it will be useful when I travel overseas. & 1234 \\
\hline $\begin{array}{l}\text { 43. Whenever I think of my future career, I imagine myself using } \\
\text { English. }\end{array}$ & 1234 \\
\hline 44. I study English because I would like to travel internationally. & 1234 \\
\hline
\end{tabular}

3. Other Comments

Is there any comment regarding your attitude to learning English and/or to the above issue (Motivational Orientations)?

\section{Copyrights}

Copyright for this article is retained by the author(s), with first publication rights granted to the journal.

This is an open-access article distributed under the terms and conditions of the Creative Commons Attribution license (http://creativecommons.org/licenses/by/3.0/). 